\title{
New records of anchialine fauna from the Yucatan Peninsula, Mexico
}

\author{
Fernando Alvarez ${ }^{1^{*}}$, Thomas M. Iliffe ${ }^{2}$, Sergio Benitez ${ }^{1}$, David Brankovits ${ }^{2}$ and José Luis Villalobos ${ }^{1}$ \\ 1 Colección Nacional de Crustáceos, Instituto de Biología, Universidad Nacional Autónoma de México, Apartado Postal 70-153, México 04510 D.F., México \\ 2 Texas A\&M University at Galveston, Department of Marine Biology, 200 Seawolf Parkway, OCSB \#251, Galveston, Texas 77553, USA \\ * Corresponding author. E-mail: falvarez@unam.mx
}

\begin{abstract}
New records for 17 species of crustaceans from anchialine systems in the Yucatan Peninsula, Mexico, are presented. The records come from explorations in Dzilam de Bravo, Yucatan, and from Puerto Aventuras and the Nohoch Nah Chich and Ox Bel Ha cave systems near Tulum in Quintana Roo, Mexico. For five of the 17 species dealt with here, the records presented constitute the second time those species are reported after their original descriptions. For the alpheid shrimp Yagerocaris cozumel, we present the first record of the species for continental Yucatan and for the atyid shrimp Jonga serrei, the second record from Mexico. Depth data are provided for all species.
\end{abstract}

Key words: Crustacea, anchialine, cenote, sinkhole, Yucatan, Quintana Roo

\section{INTRODUCTION}

The anchialine fauna of the Yucatan Peninsula, composed mainly of crustacean species, has been intensely studied for 25 years since the diving explorations of the Nohoch Nah Chich and Sac Actun systems in Quintana Roo began in 1987 (Gerrard 2000). However, a few widely distributed species in the peninsula were described years before (e.g., Creaseria morleyi and Typhlatya pearsei in 1936) because they could be captured from siphons inside caves with a dry initial section like Balan Canche Cave in Yucatan (Creaser 1936). Several publications have summarized what is known about the anchialine fauna of the Yucatan in different moments (Reddell 1981; Iliffe 1992, 1993; Alvarez and Iliffe 2008); in most cases a large proportion of the information has come from previous studies with very few new records appearing in each new occasion. For five species dealt with here the only previous records were those contained in the original description (i.e., Tuluweckelia cernua, Holsinger 1990; Metacirolana mayana, Bowman 1987; Typhlatya dzilamensis, Alvarez et al. 2005; Yagerocaris cozumel, Kensley 1988; Calliasmata nohochi, Escobar-Briones et al. 1997); and for one species, the atyid Jonga serrei (Bouvier 1909), the record presented in this contribution is the second one for Mexico.

We present herein new records for 17 species from 7 cenotes (Figure 1). Although the distribution data are important to better define particular distribution ranges, these records, mostly obtained during 2013, are evidence of the current presence of the species in a region that is being rapidly developed. The northeastern portion of the Yucatan Peninsula, where the Cancún-Tulum tourist corridor known as the "Riviera Maya" is located, is also the area where the largest anchialine systems are found. The rapid growth of the tourist infrastructure may compromise in the near future the preservation of these underground reservoirs. The northern coast of the peninsula is also being rapidly developed from the Port of Progreso to the east, where a number of cenotes are located. The periodic monitoring of anchialine species will become increasingly important in the future as the present period of intense urban development continues and compromises the availability of freshwater that is drawn from the same aquifer that constitutes the anchialine systems.

\section{MATERIALS AND METHODS}

Collection of organisms was conducted by cave divers using plankton nets or individually with glass vials. A Hydrolab Multiparameter Sonde or a YSI Multiparameter Water Quality Analyzer were used to obtain water column profiles of temperature, salinity, $\mathrm{pH}$ and dissolved oxygen concentration. The depth at which every specimen was collected was recorded; all vials were numbered and after an organism was caught the depth was recorded for that vial, plankton tows were also conducted at depths that divers recorded above an below the halocline.

The localities where organisms were collected are referred to as "cenotes" or sinkholes; however, all organisms were collected from the aphotic (dark) zone of the submerged caves associated to each one of the cenotes mentioned. The records are arranged chronologically. Species identification was done with the aid of stereomicroscopes and in some cases using a compound microscope too. All specimens were collected under the scientific collector's license issued to FA (FAUT 0104) by the Mexican environmental authority (SEMARNAT). All organisms are deposited in the National Crustacean Collection (CNCR) of the Institute of Biology, UNAM, Mexico City.

\section{RESULTS}

A summary of the species recorded, the number of specimens per species, the number of cenotes they were found in and if they were collected in freshwater or saltwater appears in Table 1. Following is an individual account for each species recorded. 
Subphylum Crustacea

Class Remipedia

Order Nectiopoda

Family Speleonectidae

Xibalbanus tulumensis (Yager, 1987)

(Figure 2A)

MATERIAL EXAMINED: 2 organisms; Cenote Muknal, $18 \mathrm{~m}$ depth, Tulum, Quintana Roo, Mexico; 31 July 2013, colls. T.M.
Iliffe, D. Brankovits; CNCR 28458, 28477. 1 organism, Cenote Bang, 20 m depth, Tulum, Quintana Roo, Mexico; 1 August 2013; colls. T.M. Iliffe, D. Brankovits; CNCR 28495. 2 organisms; Cenote Odyssey, 13.4-14 $\mathrm{m}$ depth, Tulum, Quintana Roo, Mexico; 3 August 2013; colls. T.M. Iliffe, D. Brankovits; CNCR 28441, 28443.

DISTRIBUTION: The known range of the species is from Cenote Crustacea, south of Puerto Morelos, to cenotes around Tulum, Quintana Roo, Mexico (Yager 1987; Alvarez and Iliffe 2008).
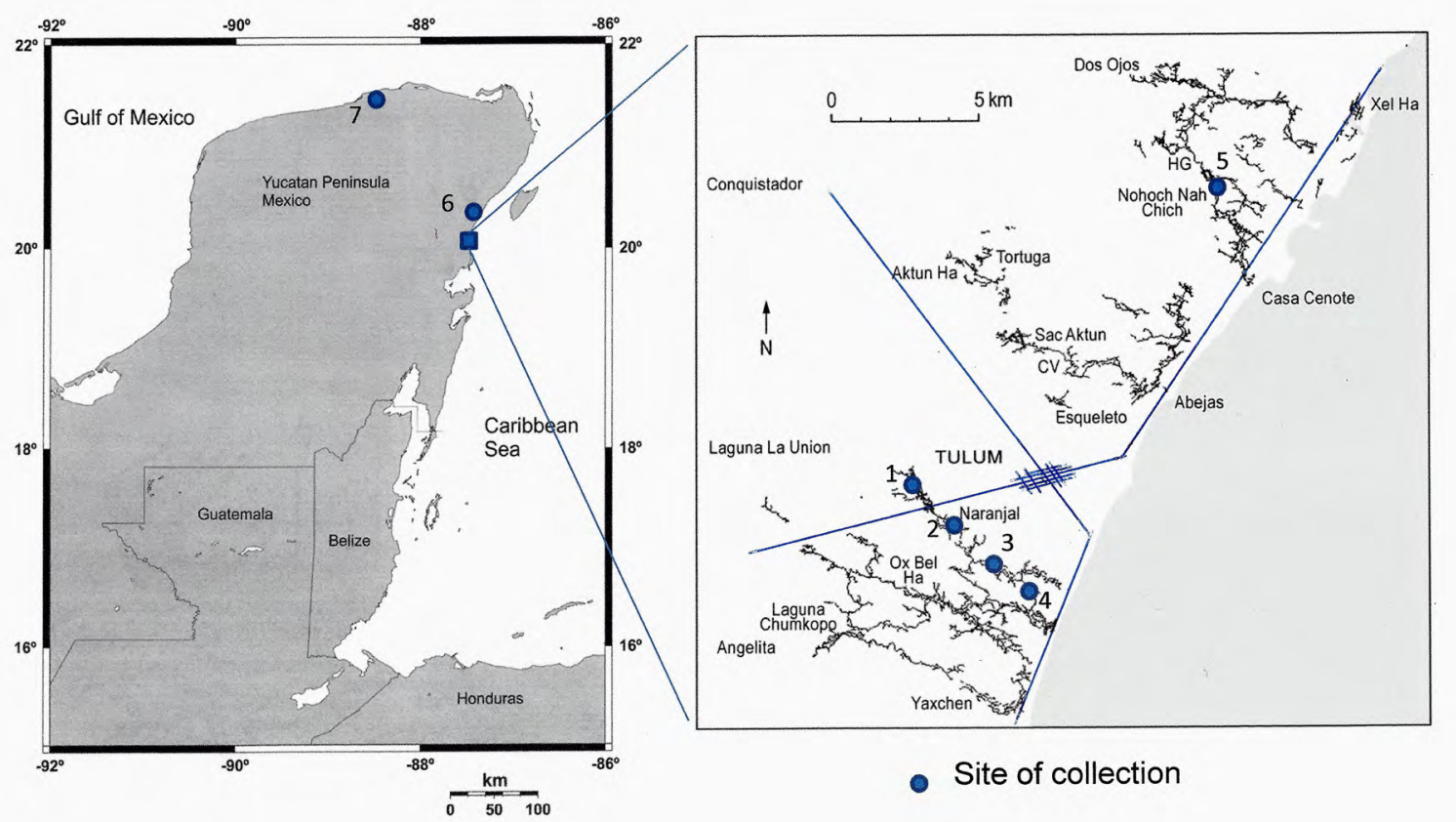

Figure 1. Map of the Yucatan Peninsula showing sites of collection: 1, Cenote Bang; 2, Cenote Muknal; 3, Cenote Odyssey; 4, Cenote Na'ach Wennen Ha; 5, Cenote Nohoch Nah Chich; 6, Cenote Eden; 7, Cenote Cervera.

Table 1. List of crustacean species and number of specimens collected from cenotes (caves) in the Yucatan Peninsula of Mexico. CB, Cenote Bang; $C M$, Cenote Muknal; CO, Cenote Odyssey; CW, Cenote Na'ach Wennen Ha; CN, Cenote Nohoch Nah Chich; CE, Cenote Eden; CC, Cenote Cervera.

\begin{tabular}{|c|c|c|c|c|c|c|c|c|c|}
\hline Taxa & Salinity & CB & CM & CO & CW & CN & CE & CC & Total Specimens \\
\hline \multicolumn{10}{|l|}{ Remipedia } \\
\hline Xibalbanus tulumensis (Yager, 1987) & SW & 1 & 2 & 2 & & & & & 5 \\
\hline \multicolumn{10}{|l|}{ Ostracoda } \\
\hline Humphreysella mexicana (Kornicker and Iliffe, 1989) & SW & 3 & 1 & & & & & & 4 \\
\hline \multicolumn{10}{|l|}{ Thermosbaenacea } \\
\hline Tulumella unidens Bowman and Iliffe, 1988 & FW & 6 & 9 & 6 & 22 & & & & 43 \\
\hline \multicolumn{10}{|l|}{ Mysida } \\
\hline Antromysis cenotensis Creaser, 1936 & FW & & 4 & 10 & & & & & 14 \\
\hline Stygiomysis cokei Kallmeyer and Carpenter, 1996 & FW & & 1 & & 7 & & & & 8 \\
\hline Stygiomysis cf. holthuisi (Gordon, 1958) & FW & 2 & 1 & 1 & 4 & & & & 8 \\
\hline \multicolumn{10}{|l|}{ Amphipoda } \\
\hline Mayaweckelia cenoticola Holsinger, 1977 & FW & & & 1 & & & & & 1 \\
\hline Tuluweckelia cernua Holsinger, 1990 & FW & 4 & 1 & 3 & 10 & & & & 18 \\
\hline \multicolumn{10}{|l|}{ Isopoda } \\
\hline Metacirolana mayana (Bowman, 1987) & SW & 3 & & 6 & & & & & 9 \\
\hline Creaseriella anops (Creaser, 1936) & FW & 6 & 8 & 3 & 1 & & & & 18 \\
\hline \multicolumn{10}{|l|}{ Decapoda } \\
\hline Jonga serrei (Bouvier, 1909) & FW & & & & & 7 & & & 7 \\
\hline Typhlatya dzilamensis Alvarez, Iliffe and Villalobos, 2005 & SW & & & & & & & 2 & 2 \\
\hline Typhlatya mitchelli Hobbs and Hobbs, 1976 & FW & 5 & 10 & 9 & 11 & & & & 35 \\
\hline Typhlatya pearsei Creaser, 1936 & $\mathrm{FW} / \mathrm{SW}$ & 1 & & 6 & 5 & & & & 12 \\
\hline Yagerocaris cozumel Kensley, 1988 & - & & & & & & 1 & & 1 \\
\hline Creaseria morleyi (Creaser, 1936) & FW & 1 & 2 & 1 & & & & & 4 \\
\hline Calliasmata nohochi Escobar-Briones, Camacho and Alcocer, 1997 & SW & & 1 & & & & & & 1 \\
\hline
\end{tabular}


REMARKS: Previously known as Speleonectes tulumensis Yager, 1987, this species has now been placed in the new genus Xibalbanus based on a molecular phylogenetic analysis of the entire class Remipedia (Hoenemann et al. 2013). It occurs at depths below $12 \mathrm{~m}$, beneath the halocline, at salinities above $32 \mathrm{ppt}$. The records presented herein correspond to cenotes 4 to $10 \mathrm{~km}$ inland from the coastline.

The species is listed in the Mexican Red List of Threatened Species (Semarnat 2010) as in danger of extinction; although it can be relatively common in a few cenotes, its distribution range is restricted to some cenotes in the Puerto MorelosTulum area.

\section{Class Ostracoda}

Family Thaumatocyprididae

Humphreysella mexicana (Kornicker \& Iliffe, 1989)

(Figure 2B)

Material EXAMINED: 1 organism; Cenote Muknal, $7 \mathrm{~m}$ depth, Tulum, Quintana Roo, Mexico; 25 February 2013; colls. T.M. Iliffe, D. Brankovits; CNCR 27888. 2 organisms; Cenote Bang, 17-22 m depth, Tulum, Quintana Roo, Mexico; 28 February 2013, coll. D. Brankovits; CNCR 27951, 27967. 1 organism; Cenote Bang, $18 \mathrm{~m}$ depth, Tulum, Quintana Roo, Mexico; 1 August 2013, coll. T.M. Iliffe; CNCR 28501.

Distribution: The type locality is Cenote Cristal, Tulum, Quintana Roo, Mexico, but also known from Cenote Ponderosa in Puerto Aventuras, and Cenote 27 Steps in Akumal, Quintana Roo, Mexico (Kornicker and Iliffe 2000).

REMARKS: Previously known as Danielopolina mexicana, this species was reassigned to Humphreysella together with other species from around the Caribbean (Iglikowska and Boxshall 2013). The present records expand the presence of this species into the Ox Bel Ha System, showing that it prefers moderate salinities near the halocline and cenotes that are 6 to $10 \mathrm{~km}$ inland from the coastline.

Class Malacostraca

Superorder Peracarida

Order Thermosbaenacea

Family Tulumellidae

\section{Tulumella unidens Bowman \& Iliffe, 1988}

\section{(Figure 2C)}

Material EXAMINED: 2 organisms; Cenote Muknal, depth 13 m, Tulum, Quintana Roo, Mexico; 25 February 2013; colls. T.M. Iliffe, D. Brankovits, B. Phillips; CNCR 27895, 27904. 6 organisms; Cenote Na'ach Wennen Ha, 5-9 m depth, Tulum, Quintana Roo, Mexico; 27 February 2013; colls. T.M. Iliffe, D. Brankovits, B. Phillips; CNCR 27933-27935, 27939, 27948. 4 organisms; Cenote Bang, depth 10-25 m, Tulum, Quintana Roo, Mexico; 28 February 2013; colls. T.M. Iliffe, D. Brankovits, B. Phillips; CNCR 27953, 27958, 27966, 27971. 2 organisms; Cenote Muknal, depth 16 m; Tulum, Quintana Roo, Mexico; 31 July 2013; colls. T.M. Iliffe, D. Brankovits, T. Winkler; CNCR 28472, 28490. 1 organism, Cenote Odyssey, depth 13 m, Tulum, Quintana Roo, Mexico; 2 August 2013; colls. T.M. Iliffe, D. Brankovits, T. Winkler; CNCR 28435. 12 organisms; Cenote Na'ach Wennen Ha, 5.2-10.1 m depth, Tulum, Quintana Roo, Mexico; 3 August 2013; colls. T.M. Iliffe, D. Brankovits, T. Winkler; CNCR 28391, 28393, 28404, 28414, 28423. 5 organisms;
Cenote Muknal, depth 8.5-16 m; Tulum, Quintana Roo, Mexico; 4 December 2013; colls. T.M. Iliffe, D. Brankovits, T. Winkler; CNCR 28472, 28490, 28613, 28616, 28617. 2 organisms; Cenote Bang, depth 10-11 m, Tulum, Quintana Roo, Mexico; 5 December 2013; colls. T.M. Iliffe, D. Brankovits, T. Winkler; CNCR 28620, 28625. 5 organisms; Cenote Odyssey, depth 4.6-7.6 m, Tulum, Quintana Roo, Mexico; 7 December 2013; colls. T.M. Iliffe, D. Brankovits, T. Winkler; CNCR 28583, 28592, 28593. 4 organisms; Cenote Na'ach Wennen Ha, depth 6-8.8 m, Tulum, Quintana Roo, Mexico; 8 December 2013; colls. T.M. Iliffe, D. Brankovits, T. Winkler; CNCR 28540, 28552.

Distribution: Cenotes Cristal, Calavera and Actun Ha, Tulum, Quintana Roo, Mexico (Bowman and Iliffe 1988; Alvarez and Iliffe 2008).

REMARKS: This species is locally abundant in cenotes around the town of Tulum, and is present throughout the $\mathrm{Ox}$ Bel Ha System in cenotes that range from 2 to $10 \mathrm{~km}$ from the coastline. Inside the caves, T. unidens is found at depths ranging from 4.6 to $25 \mathrm{~m}$, always above the halocline.

\section{Order Mysida}

Family Mysidae

\section{Antromysis cenotensis Creaser, 1936 \\ (Figure 2D)}

MAterial EXAMINED: 4 organisms; Cenote Muknal, depth 13-16 m, Tulum, Quintana Roo, Mexico; 25 February 2013; coll. T.M. Iliffe; CNCR 27885, 27892, 27908, 27911. 6 organisms; Cenote Odyssey, depth 14 m, Tulum, Quintana Roo, Mexico; 26 February 2013, coll. T.M. Iliffe, D. Brankovits, B. Phillips; CNCR 27916, 27236. 4 organisms; Cenote Odyssey, depth 4.6 m, Tulum, Quintana Roo, Mexico; 2 August 2013; colls. T.M. Iliffe, D. Brankovits, T. Winkler; CNCR 28446-28449.

DISTRIBUTION: Widely distributed in the central and northern portions of the Yucatan Peninsula (Reddell 1981; Alvarez and Iliffe 2008). Present in Quintana Roo from a number of cenotes in Sian Ka'an and the Tulum-Cobá region. In Yucatan it has been recorded from Grutas de Balancanché, Tinúm; and a number of cenotes that form the ring of cenotes around the city of Merida (Reddell 1981; Pérez-Aranda 1984c).

REMARKS: Although this species is listed in the Mexican Red List of Threatened Species (Semarnat 2010) as threatened, it is widely distributed and very abundant, often forming swarms of hundreds of organisms. A. cenotensis occurs preferentially above the halocline, from the surface to $16 \mathrm{~m}$ depths; however, it can occasionally be found below the halocline in moderate salinities.

\section{Family Stygiomysidae}

\section{Stygiomysis cokei Kallmeyer \& Carpenter, 1996 \\ (Figure 2E)}

MATERIAL EXAMINED: 3 organisms; Cenote Na'ach Wennen Ha, depth 7-8 m, Tulum, Quintana Roo, Mexico; 27 February 2013; colls. T.M. Iliffe, D. Brankovits, B. Phillips; CNCR 27938, 27941, 27946. 1 organism; Cenote Muknal, depth $15.5 \mathrm{~m}$, Tulum, Quintana Roo, Mexico; 31 July 2013; coll. T.M. Iliffe; CNCR 28478. 4 organisms; Cenote Na'ach Wennen Ha, depth 6-9.8 m, Tulum, Quintana Roo, Mexico; 3 August 2013; colls. 

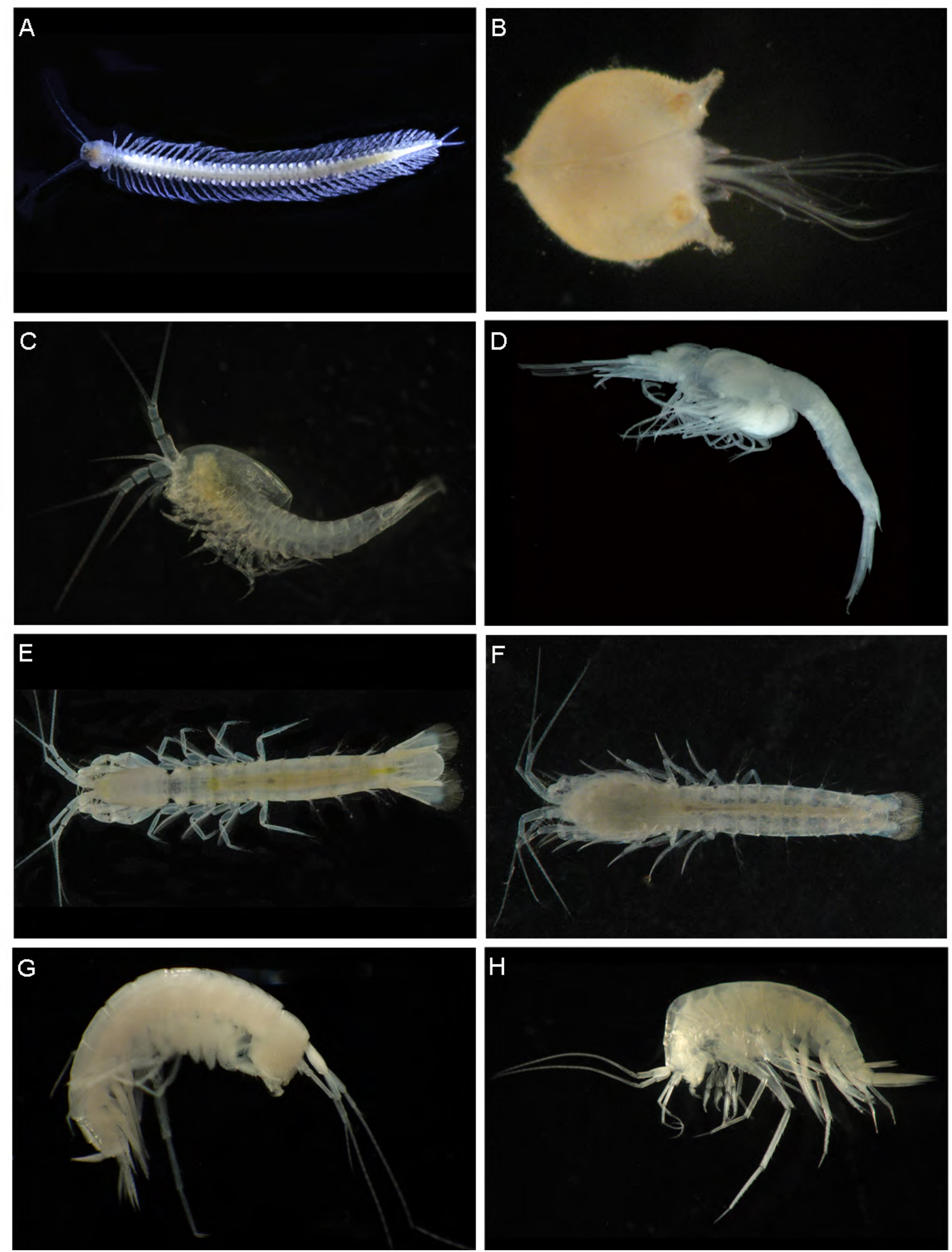

Figure 2. A, Xibalbanus tulumensis (Remipedia); B, Humphreysella mexicana (Ostracoda); C, Tulumella unidens (Thermosbaenacea); D, Antromyisis cenotensis (Mysida); E, Stygiomysis cokei (Mysida); F, Stygiomysis cf. holthuisi (Mysida); G, Mayaweckelia cenoticola (Amphipoda); Tuluweckelia cernua (Amphipoda). 
T.M. Iliffe, D. Brankovits, T. Winkler; CNCR 28395, 28401, 28410.

Distribution: In Quintana Roo: Cenotes Calavera, Escondido, Actun Ha, Cristal and Actun Ko; in Yucatan: Cenotes Pabakal, San Eduardo, Kankirixché, Mucuyché and Dzonotila (Pesce and Iliffe 2002).

REMARKS: The present records show that $S$. cokei occurs in low salinities (2-5 ppt) above the halocline in cenotes 2 to 4 $\mathrm{km}$ inland from the coastline.

\section{Stygiomysis cf. holthuisi (Gordon, 1958)}

\section{(Figure 2F)}

MATERIAL EXAMINED: 3 organisms; Cenote Na'ach Wennen Ha, depth 7-10 m, Tulum, Quintana Roo, Mexico; 27 February 2013; colls. T.M. Iliffe, D. Brankovits, B. Phillips; CNCR 27932, 27937, 27945. 2 organisms; Cenote Bang, depth 13 m, Tulum, Quintana Roo, Mexico; 28 February 2013; colls. T.M. Iliffe, D. Brankovits, B. Phillips; CNCR 27968, 27976. 1 organism; Cenote Muknal, depth 15.2 m, Tulum, Quintana Roo, Mexico; 31 July 2013; colls. T.M. Iliffe, D. Brankovits, T. Winkler; CNCR 28482. 1 organism; Cenote Odyssey, depth 14.6 m, Tulum, Quintana Roo, Mexico; 2 August 2013; colls. T.M. Iliffe, D. Brankovits, T. Winkler; CNCR 28445. 1 organism; Cenote Na'ach Wennen Ha, depth 8.2 m, Tulum, Quintana Roo, Mexico; 3 August 2013; colls. T.M. Iliffe, D. Brankovits, T. Winkler; CNCR 28394.

Distribution: Stygiomysis holthuisi was described from material collected in St. Martin, Lesser Antilles (Gordon 1958), and was subsequently reported from Puerto Rico, Anguilla and the Bahamas (Bowman et al. 1984). Pesce and Iliffe (2002) reported the species from cenotes in Quintana Roo (Escondido and Casa Cenote) and Yucatan (Mucuyché), Mexico.

REMARKS: The organisms identified as Stygiomysis holthuisi from the Yucatan Peninsula agree well, but not completely, with the description of the species. Pesce and Iliffe (2002) had already pointed out several differences seen in the Yucatan organisms, to which we could add a larger uropod length in relation to the telson length. It seems very possible that a new species will be erected to accommodate the Yucatan specimens.

Order Amphipoda

Family Hadziidae

\section{Mayaweckelia cenoticola Holsinger, 1977}

(Figure 2G)

Material EXAMINeD: 1 organism; Cenote Odyssey, depth 6.1 m, Tulum, Quintana Roo, Mexico; 7 December 2013; coll. T.M. Iliffe; CNCR 28596.

Distribution: Along the northern portion of the Yucatan Peninsula (Holsinger 1977; Reddell 1981).

REMARKS: Although this species has been regarded as common in other parts of the Yucatan Peninsula, it is rare in the Ox Bel Ha System, appearing only once at moderate depth in freshwater.

\section{Tuluweckelia cernua Holsinger, 1990}

(Figure 2H)

MATERIAL EXAMINED: 7 organisms; Cenote Narach Wennen Ha, depth 6-9 m, Tulum, Quintana Roo, Mexico; 27
February 2013; colls. T.M. Iliffe, D. Brankovits; CNCR 27928, 27940, 27942, 27943, 27947, 27949. 2 organisms; Cenote Bang, depth 12-14 m, Tulum, Quintana Roo, Mexico; 28 February 2013; coll. T.M. Iliffe; CNCR 27961, 27970. 1 organism; Cenote Muknal, depth $12.8 \mathrm{~m}$, Tulum, Quintana Roo, Mexico; 31 July 2013; colls. T.M. Iliffe; CNCR 28479. 2 organisms; Cenote Bang, depth 8-16 m, Tulum, Quintana Roo, Mexico; 1 August 2013; colls. T.M. Iliffe, D. Brankovits, T. Winkler; CNCR 28497, 28498. 1 organism; Cenote Odyssey, depth $8.8 \mathrm{~m}$, Tulum, Quintana Roo, Mexico; 2 August 2013; coll. D. Brankovits; CNCR 28433. 3 organisms; Cenote Narach Wennen Ha, depth 4-10.1 m, Tulum, Quintana Roo, Mexico; 3 August 2013; colls. T.M. Iliffe, D. Brankovits, T. Winkler; CNCR 28387, 28400, 28422. 2 organisms; Cenote Odyssey, depth 9.1-13.7 m, Tulum, Quintana Roo, Mexico; 7 December 2013; colls. T.M. Iliffe, D. Brankovits; CNCR 28580, 28611.

Distribution: In Quintana Roo in the following cenotes around Tulum: Calavera, Aktun Ha, Escondido, Mojarra and Cristal (Holsinger 1990).

REMARKS: The records presented herein are the first to be published about T. cernua after Holsinger (1990). The species is common in the Ox Bel Ha System; it is clearly a freshwater species occurring always above the halocline to depths of $16 \mathrm{~m}$.

\section{Order Isopoda}

Family Cirolanidae

\section{Metacirolana mayana (Bowman, 1987)}

\section{(Figure 3A)}

MATERIAL EXAMINED: 1 organism; Cenote Bang, depth 19 m, Tulum, Quintana Roo, Mexico; 28 February 2013, coll. T.M. Iliffe; CNCR 27954. 2 organisms; Cenote Bang, depth 19-21 m, Tulum, Quintana Roo, Mexico; 1 August 2013; colls. T.M. Iliffe, D. Brankovits; CNCR 28499, 28504. 3 organisms; Cenote Odyssey, depth 14-15 m, Tulum, Quintana Roo, Mexico; 2 August 2013; colls. T.M. Iliffe, D. Brankovits, T. Winkler; CNCR 28439, 28451, 28456. 3 organisms; Cenote Odyssey, depth $15 \mathrm{~m}$, Tulum, Quintana Roo, Mexico; 7 December 2013; colls. T.M. Iliffe, D. Brankovits, T. Winkler; CNCR 28599, 28604, 28608.

Distribution: Known from Quebrada Cave in Chankanaab Park, Cozumel and Cenote Calavera, Tulum, Quintana Roo, Mexico (Bowman 1987).

REMARKS: The records presented herein are the first to be published after Bowman (1987) original description of the species. Metacirolana mayana was always collected at or below the halocline in salinities of 32 ppt or higher.

\section{Creaseriella anops (Creaser, 1936)}

\section{(Figure 3E)}

MATERIAL EXAMINED: 7 organisms; Cenote Muknal, 8-16 m depths, Tulum, Quintana Roo, Mexico; 25 February 2013; colls. T.M. Iliffe, D. Brankovits, B. Phillips; CNCR 27874, 27899, 27902, 27903, 27909, 27910, 27912. 2 organisms; Cenote Odyssey, depth 13-14 m, Tulum, Quintana Roo, Mexico; 26 February 2013; colls. T.M. Iliffe, D. Brankovits; CNCR 27917, 27920. 1 organim; Cenote Na'ach Wennen Ha, depth 8 m, Tulum, Quintana Roo, Mexico; 27 February 2013, coll. D. Brankovits; CNCR 27927. 5 organisms; Cenote Bang, depth 12-17 m, Tulum, Quintana Roo, Mexico; 28 February 2013; colls. T.M. Iliffe, D. Brankovits, T. Winkler; CNCR 27956, 27957, 2796o, 27962, 27973. 1 organism; Cenote Bang, 

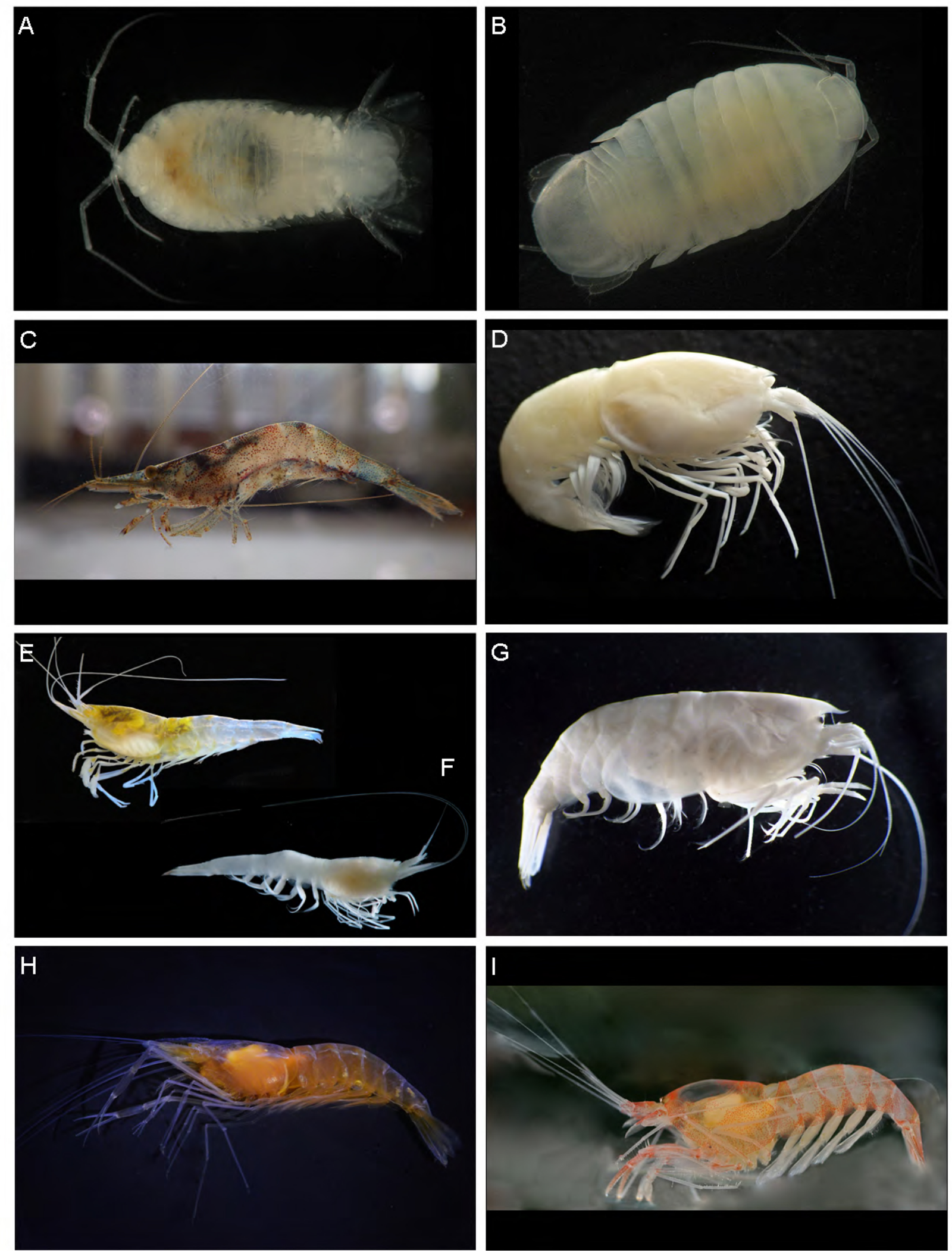

Figure 3. A, Metacirolana mayana (Isopoda); B, Creaseriella anops (Isopoda); C, Jonga serrei (Atyidae); D, Typhlatya dzilamensis (Atyidae); E, Typhlatya mitchelli (Atyidae); F, Typhlatya pearsei (Atyidae); G, Yagerocaris cozumel (Alpheidae); H, Creaseria morleyi (Palaemonidae); I, Calliasmata nohochi (Hippolytidae). 
depth 5 m, Tulum, Quintana Roo, Mexico; 1 August 2013; coll. D. Brankovits; CNCR 28491. 1 organism; Cenote Odyssey, depth 15 m, Tulum, Quintana Roo, Mexico; 2 August 2013; coll. T.M. Iliffe; CNCR 28440. 1 organism; Cenote Muknal, depth $10 \mathrm{~m}$, Tulum, Quintana Roo, Mexico; 8 December 2013; coll. D. Brankovits; CNCR 28615 .

DISTRIBUTION: Throughout the central and northern portions of the Yucatan Peninsula, Mexico (Pérez-Aranda 1984b; Alvarez and Iliffe 2008).

REMARKS: Creaseriella anops is listed in Mexican Red List of Threatened Species (Semarnat 2010) as threatened; however, the species is usually common within its range and depending on the sampling method, it can be abundant. It was present in all cenotes studied in the Ox Bel Ha System.

Order Decapoda

Family Atyidae

\section{Jonga serrei (Bouvier, 1909)}

(Figure 3C)

MATERIAL EXAMINED: 7 organisms; Cenote Nohoch Nah Chich, depth o-8 m, Quintana Roo, Mexico; 28 June 2014; colls. T.M. Iliffe, J.L. Villalobos, S. Benitez; CNCR 29150.

Distribution: Cuba, Jamaica, Puerto Rico, Dominica, Barbados, Costa Rica and Mexico (Chace and Hobbs 1969; Alvarez and Iliffe 2008).

REMARKS: Alvarez and Iliffe (2008) first reported this species from Cenote del Mar, south of Tulum, Quintana Roo. The present record is the second for the species in Mexico. Although considered to be a coastal species, the two records from Mexico are from caves. The organisms collected are pigmented with normal eyes, not showing any obvious adaptation to cave life, and, as pointed out by Alvarez and Iliffe (2008), the Mexican organisms are larger (26 $\mathrm{mm}$ of total length (TL)) than those previously reported from around the Caribbean ( $15 \mathrm{~mm}$ TL). In Cenote Nohoch Nah Chich, this species occurs in the cave entrance in semi-darkness and inside the cave.

\section{Typhlatya dzilamensis Alvarez, Iliffe \& Villalobos, 2005}

\section{(Figure 3D)}

Material examined: 2 organisms; Cenote Cervera, depth 10-12 m, Dzilam de Bravo, Yucatan, Mexico; 6 December 2013; colls. T.M. Iliffe, D. Brankovits; CNCR 29057.

Distribution: Only known from two cenotes in the town of Dzilam de Bravo, Yucatan and one from Buya Uno, a marine cave $300 \mathrm{~m}$ offshore from the town in the Gulf of Mexico (Alvarez et al. 2005).

REMARKS: The record presented herein represents the second time the species is collected. The first collections of the species used to describe it were made in 2002 (Alvarez et al. 2005). Typhlatya dzilamensis was collected again in the type locality at depths ranging between 10-12 $\mathrm{m}$ in fully marine water, while T. mitchelli was also found at depths shallower than $4 \mathrm{~m}$ in freshwater.

\section{Typhlatya mitchelli Hobbs \& Hobbs, 1976}

\section{(Figure 3E)}

Material EXAMINed: 5 organisms; Cenote Muknal, depth 9-11 m, Tulum, Quintana Roo, Mexico; 25 February 2013; colls. T.M. Iliffe, D. Brankovits, B. Phillips; CNCR 27866, 27891,
27893, 27894, 27906. 2 organisms; Cenote Odyssey, depth 10 m, Tulum, Quintana Roo, Mexico; 26 February 2013; colls. T.M. Iliffe, D. Brankovits, B. Phillips; CNCR 27915, 27918. 4 organisms; Cenote Na'ach Wennen Ha, depth 7-8 m, Tulum, Quintana Roo, Mexico; 27 February 2013, colls. T.M. Iliffe, D. Brankovits; CNCR 27929, 27931, 27944, 27950. 2 organisms, Cenote Na'ach Wennen Ha, depth 8-13 m, Tulum, Quintana Roo, Mexico; 28 February 2013; colls. T.M. Iliffe, D. Brankovits, B. Phillips; CNCR 27955, 27963. 3 organisms; Cenote Muknal, depth 8-11 m, Tulum, Quintana Roo, Mexico; 31 July 2013; colls. T.M. Iliffe, D. Brankovits, T. Winkler; CNCR 28470, 28476, 28486. 2 organisms; Cenote Bang, depth 14-18 m, Tulum, Quintana Roo, Mexico; 1 August 2013; colls. T.M. Iliffe, D. Brankovits; 28492, 28493. 5 organisms; Cenote Odyssey, depth 4.6-10.4 m, Tulum, Quintana Roo, Mexico; 2 August 2013; colls. T.M. Iliffe, D. Brankovits, T. Winkler; CNCR 28432, 28434, 28436, 28437, 28450. 4 organisms; Cenote Na'ach Wennen Ha, depth 4.2-10.1 m, Tulum, Quintana Roo, Mexico; 3 August 2013; colls. T.M. Iliffe, D. Brankovits, T. Winkler; CNCR 28402, 28403, 28405, 28415. 2 organisms; Cenote Muknal, depth 7.3-8.5 m, Tulum, Quintana Roo, Mexico; 4 December 2013; colls. T.M. Iliffe, D. Brankovits; CNCR 28614, 28618. 3 organisms; Cenote Bang, depth 9-16 m, Tulum, Quintana Roo, Mexico; 5 December 2013; colls. T.M. Iliffe, D. Brankovits, T. Winkler; CNCR 28624, 28630, 28634. 2 organisms; Cenote Odyssey, depth 6-9 m, Tulum, Quintana Roo, Mexico; 7 December 2013; colls. T.M. Iliffe, D. Brankovits; CNCR 28584, 28586. 1 organism; Cenote Na'ach Wennen Ha, depth 7.9 m, Tulum, Quintana Roo, Mexico; 8 December 2013; coll. T Winkler; CNCR 28572.

Distribution: Throughout the Yucatan Peninsula, from the western portion at Maxacanú, south of Merida, Yucatan, to the cenotes between Akumal and Tulum, Quintana Roo; to the north it occurs near Tizimin, Yucatan, Mexico (PérezAranda 1984a; Alvarez and Iliffe 2008).

REMARKS: This species is listed in the Mexican Red List of Threatened Species (Semarnat 2010) as threatened; however, similar to other anchialine species, it is very common within its range. It occurs from the surface in cave pools to depths of $18 \mathrm{~m}$, always in freshwater. T. mitchelli is considered as a common species in the Ox Bel Ha System.

\section{Typhlatya pearsei Creaser, 1936}

\section{(Figure 3F)}

MATERIAL EXAMINED: 2 organisms; Cenote Odyssey, depth 13-15 m, Tulum, Quintana Roo, Mexico; 26 February 2013; colls. T.M. Iliffe, D. Brankovits, B. Phillips; CNCR 27921, 27925. 1 organism; Cenote Narach Wennen Ha, depth $8 \mathrm{~m}$, Tulum, Quintana Roo, Mexico; 27 February 2013; coll. D. Brankovits; CNCR 27930. 1 organism; Cenote Bang, depth $12 \mathrm{~m}$, Tulum, Quintana Roo, Mexico; 28 February 2013; coll. D. Brankovits; CNCR 27969. 2 organisms; Cenote Narach Wennen Ha, depth 6.9-8.2 m, Tulum, Quintana Roo, Mexico; 3 August 2013; colls. T.M. Iliffe, D. Brankovits; CNCR 28397, 28417. 4 organisms; Cenote Odyssey, depth 4-14 m, Tulum, Quintana Roo, Mexico; colls. T.M. Iliffe, D. Brankovits, T. Winkler; CNCR 28581, 28585, 2859o, 28602. 2 organisms; Cenote Narach Wennen Ha, depth 6.4-8.8 m, Tulum, Quintana Roo, Mexico; 8 December 2013; colls. T.M. Iliffe, D. Brankovits, T. Winkler; CNCR 28541, 28574 . 
DISTRIBUTION: Widely distributed in the northern portion of the Yucatan Peninsula. It occurs from Champoton, Campeche, to Telchac Puerto in the northern coast of Yucatan, to the cenotes in the area of Tulum and Akumal, Quintana Roo (Perez-Aranda 1983b).

REMARKS: This species is listed in Mexican Red List of Threatened Species (Semarnat 2010) as threatened; however, this is the species of Typhlatya in the Yucatan Peninsula with the largest distribution range. It occurs in freshwater above the halocline to depths of $15 \mathrm{~m}$.

Family Alpheidae

\section{Yagerocaris cozumel Kensley, 1988}

(Figure 3G)

Material EXAMINED: 1 organism; Cenote Eden, Solidaridad, Quintana Roo, Mexico; 30 July 2006; coll. T.M. Iliffe; CNCR 24869.

Distribution: Previously known from Cenote Aerolito which is the type locality of the species, and Cueva la Quebrada, Chankanaab Park; both sites in the island of Cozumel, Quintana Roo, Mexico (Kensley 1988).

REMARKS: The present record extends the distribution of the species to continental Yucatan, since it was previously considered an insular species from the island of Cozumel (Alvarez and Iliffe 2008). The present record is also the first one to appear since the description of the species by Kensley (1988).

Family Palaemonidae

\section{Creaseria morleyi (Creaser, 1936)}

(Figure 3H)

Material eXAMined: 1 organism; Cenote Bang, depth 16 m, Tulum, Quintana Roo, Mexico; 28 February 2013; coll. D. Brankovits; CNCR 27959. 2 organisms; Cenote Muknal, depth 14-15 m, Tulum, Quintana Roo, Mexico; 31 July 2013; colls. T.M. Iliffe, D. Brankovits; CNCR 28464, 28467. 1 organism; Cenote Na'ach Wennen Ha, depth 10 m, Tulum, Quintana Roo, Mexico; 3 August 2013; coll. T.M. Iliffe; CNCR 28425.

Distribution: Widely distributed in the northern section of the Yucatan Peninsula in Yucatan and Quintana Roo. The species has been recorded from many cenotes composing the "Ring of Cenotes" around the City of Merida, but also from the cenotes along the coast of Quintana Roo (Perez-Aranda 1983a; Botello and Alvarez 2006, 2010).

REMARKS: This species is listed in Mexican Red List of Threatened Species (Semarnat 2010) as threatened. C. morleyi is one of the species with the widest distribution in the Yucatan Peninsula, it occurs mostly in freshwater at shallow depths to $16 \mathrm{~m}$.

Family Hippolytidae

Calliasmata nohochi Escobar-Briones, Camacho \& Alcocer, 1997 (Figure 3I)

Material eXAmined: 1 organism; Cenote Muknal, depth 18 m, Tulum, Quintana Roo, Mexico; 31 July 2013; coll. T.M. Iliffe; CNCR 28483.

Distribution: Previously known only from two caves: Cenote Crack House (type locality), in the Nohoch Nah Chich
System; and Cenote Escondido, in the Ox Bel Ha System.

REMARKS: This is a very rare species that has been collected only three times, the material from the first two collections is mentioned in the description of the species (Escobar-Briones et al. 1997). The new record comes from Cenote Muknal, which is also part of the Ox Bel Ha System, to the southeast of Cenote Escondido.

\section{DISCUSSION}

Until now, 45 anchialine species of crustaceans from the Yucatan Peninsula have been recognized (Alvarez and Iliffe 2008; Alvarez et al. 2012; Neiber et al. 2012; Boxshall et al. 2014); other anchialine fauna include an undescribed species of gastropod, one or possibly two echinoderms (Solís-Marín and Laguarda-Figueras 2010) and two species of fish (Alvarez and Iliffe 2008). We estimate that 31, out of the known 45 crustacean species, could have been collected during the present survey as they are widely distributed in Quintana Roo or have more ample distribution ranges. The other 14 species are known only from their type locality in the states of Yucatan and Campeche or are restricted to the island of Cozumel. We report on 17 species, $55 \%$ of the possible 31 species, however no copepods are included in this paper as they will be treated in an upcoming contribution on anchialine plankton.

Regarding the identity of the organisms collected, all could be readily identified to species, except the mysid shrimp referred to here as Stygiomysis cf. holthuisi. In this case, several characters do not agree completely with the original description; a comparative study with samples from other locations in the Yucatan Peninsula and from around the Caribbean region would be necessary to determine if this is a wide ranging species with a significant degree of morphological variation or a species complex. In the case of Jonga serrei, even when the closest records are those from Cuba and Costa Rica, no significant variation from the description was noted.

Our results confirm a wide distribution for several species, a pattern that is consistent with the degree of connectivity that has become apparent in the anchialine systems of the eastern portion of Quintana Roo, where cenotes, kilometers of passageways, and new connections between systems, are being discovered and explored each year (Bauer-Gottwein et al. 2011). The records presented herein expand the distribution ranges of 9 of the 17 reported species and represent for five species the second time they are collected after their original description. Six of the 17 species reported herein are included in the Mexican Red List of Threatened Species (Semarnat 2010). Considering the new records, the hadziid Tuluweckelia cernua, the cirolanid Metacirolana mayana, the atyid Typhlatya dzilamensis, the alpheid Yagerocaris cozumel, and the hippolytid Calliasmata nohochi, should be included in the Red List due to their confirmed reduced distribution range and/or to the low numbers that have been collected that suggest very small natural populations.

\section{ACKNOWLEDGMENTS}

The first author gratefully acknowledges the funding awarded through CONACYT grant 155644(546) "Processes that create and maintain the biodiversity in an extreme environment: the anchialine systems of Yucatan". Additional funding was provided to the first two authors through a Texas 
A\&M University - CONACYT collaborative science grant \#10655 "What promotes species diversification in anchialine habitats?". S. Benitez acknowledges the support received through a CONACYT scholarship. D. Brankovits sincerely thanks for the support of the Rufford Foundation and the National Speleological Society's Ralph W. Stone Scholarship. We sincerely appreciate the assistance provided by Texas A\&M University students and staff Tyler Winkler and Brett Gonzalez, UNAM student Olinka Cortés and local cave divers Bil Phillips and Robbie Schmittner.

\section{LITERATURE CITED}

Alvarez, F. and T.M. Iliffe. 2008. Fauna anquihalina de Yucatán; pp. 379-418, in: F. Alvarez and G. Rodríguez-Almaraz (eds.). Crustáceos de México: Estado Actual de su Conocimiento. Universidad Autónoma de Nuevo León-PROMEP.

Alvarez, F., T.M. Iliffe and J.L. Villalobos. 2005. New species of the genus Typhlatya (Decapoda: Atyidae) from anchialine caves in Mexico, the Bahamas and Honduras. 2005. Journal of Crustacean Biology 25(1): 81-94 (doi: 10.1651/C-2516).

Alvarez, F., T.M. Iliffe, B. Gonzalez and J.L. Villalobos. 2012. Triacanthoneus akumalensis, a new species of alpheid shrimp (Crustacea: Caridea: Alpheidae) from an anchialine cave in Quitana Roo, Mexico. Zootaxa 3154: 61-68.

Bauer-Gottwein, P., B.R.N. Gondwe, G. Chauvert, L.E. Marín, M. Rebolledo-Vieyra and G. Merediz-Alonso. 2011. The Yucatán Peninsula karst aquifer, Mexico. Hydrogeology Journal 19(3): 507-524 (doi: 10.1007/s10040-010-0699-5).

Botello, A. and F. Alvarez. 2006. Allometric growth in Creaseria morleyi (Creaser, 1936) (Decapoda: Palaemonidae), from the Yucatan Peninsula, Mexico. Caribbean Journal of Science 42: 171-179.

Botello, A. and F. Alvarez. 2010. Genetic variation in the stygobitic shrimp Creaseria morleyi (Decapoda: Palaemonidae), evidence of bottlenecks and re-invasions in the Yucatan Peninsula. Biological Journal of the Linnean Society 99(2): 315-325 (doi: 10.1111/j.10958312.2009.01355.x).

Bouvier, E.-L. 1909. Les crevettes d'eau douce de la famille des Atyidés qui se trouvent dans l'île de Cuba. Bulletin du Muséum Natinal d'Histoire Naturelle 1909(7): 329-336 (http://biodiversitylibrary. org/page/5033196).

Bowman, T.E. 1987. Bahalana mayana, a new troglobitic cirolanid isopod from Cozumel Island and the Yucatan Peninsula, Mexico. Proceedings of the Biological Society of Washington 100: 659-663 (http://www.biodiversitylibrary.org/page/34571067).

Bowman, T.E. and T.M. Iliffe. 1988. Tulumella unidens, a new genus and species of thermosbaenacean crustacean from the Yucatan Peninsula, Mexico. Proceedings of the Biological Society of Washington 101: 221-226 (http://biodiversitylibrary.org/ page/34645902).

Bowman, T.E., T.M. Iliffe and J. Yager. 1984. New records of the troglobitic mysid genus Stygiomysis: S. clarkei, new species, from the Caicos Islands, and S. holthuisi (Gordon) from Grand Bahama Island (Crustacea: Mysidacea). Proceedings of the Biological Society of Washington 97: 637-644 (http://biodiversitylibrary.org/ page/34642466).

Boxshall, G.A., S. Zylinski, D. Jaume, T.M. Iliffe and Eduardo Suárez-Morales. 2014. A new genus of speleophriid copepod (Copepoda: Misophrioida) from a cenote in the Yucatan, Mexico with a phylogenetic analysis at the species level. Zootaxa 3821(3): 321-336 (doi: 10.11646/zootaxa.3821.3.2).

Chace, F.A., Jr. and H.H. Hobbs, Jr. 1969. The freshwater and terrestrial decapod crustaceans of the West Indies with special reference to Dominica. United States National Museum, Bulletin 292: 1-258 (http://biodiversitylibrary.org/page/7866360).
Creaser, E.P. 1936. Crustaceans from Yucatan; pp. 117-132, in: A.S. Pearse, E.P. Creaser and F.G. Hall (eds.). The Cenotes of Yucatan. Carnegie Institution, Washington, Publication 457.

Escobar-Briones, E., M.E. Camacho and J. Alcocer. 1997. Calliasmata nohochi, new species (Decapoda: Caridea: Hippolytidae), from anchialine cave systems in continental Quintana Roo, Mexico. Journal of Crustacean Biology 17(4): 733-744 (doi: 10.2307/1549376).

Gerrard, S. 2000. The Cenotes of the Riviera Maya. Tallahassee, USA Rose Printing Inc. 242 pp.

Gordon, I. 1958. A new subterranean crustacean from the West Indies. Nature 181: 1552-1553 (doi: 10.1038/1811552ao).

Hobbs, H.H., III and H.H. Hobbs, Jr. 1976. On the troglobitic shrimps of the Yucatan Peninsula, Mexico (Decapoda: Atyidae and Palaemonidae). Smithsonian Contributions to Zoology 240: 1-23.

Hoenemann, M., M.T. Neiber, W.F. Humphreys, T.M. Iliffe, D. Li, F.R. Schramm and S. Koenemann. 2013. Phylogenetic analysis and systematic revision of Remipedia (Nectiopoda) from Bayesian analysis and molecular data. Journal of Crustacean Biology 33(5): 603-619 (doi: 10.1163/1937240X-00002179).

Holsinger, J.R. 1977. A new genus and two new species of subterranean amphipod crustaceans (Gammaridae s. lat.) from the Yucatan Peninsula in Mexico. Association for Mexican Cave Studies, Bulletin 6: 15-25.

Holsinger, J.R. 1990. Tuluweckelia cernua, a new genus and species of stygobiont amphipod crustacean (Hadziidae) from anchialine caves on the Yucatan Peninsula in Mexico. Beaufortia 41: 97-107.

Iglikowska, A. and G.A. Boxshall. 2013. Danielopolina revisited: phylogenetic relationships of the extant genera of the family Thaumatocyprididae (Ostracoda: Myodocopa). Zoologischer Anzeiger 252: 469-485 (doi: 10.1016/j.jcz.2013.01.004).

Iliffe, T.M. 1992. An annotated list of the troglobitic, anchialine and freshwater cave fauna of Quintana Roo; pp. 197-215, in: D. Navarro and E. Suárez-Morales (eds.). Diversidad Biológica en la Reserva de la Biosfera de Sian Ka'an, Quintana Roo, México, Vol. II. CIQRO, Chetumal, México.

Iliffe, T.M. 1993. Fauna troglobia acuática del península de Yucatán; pp. 673-686, in: S.I. Salazar-Vallejo and N.E. González (eds.). Biodiversidad Marina y Costera de México. Conabio-CIQRO.

Kallmeyer, D.E. and J.H. Carpenter. 1996. Stygiomysis cokei, new species, a troglobitic mysid from Quintana Roo, Mexico (Mysidacea: Stygiomysidae). Journal of Crustacean Biology 16: 418-427.

Kensley, B. 1988. New species and records of cave shrimps from the Yucatan Peninsula (Decapoda: Agostocarididae and Hippolytidae). Journal of Crustacean Biology 8: 688-699.

Kornicker, L.S. and T.M. Iliffe. 1989. New Ostracoda (Halocyprida: Thaumatocyprididae and Halocyprididae) from anchialine caves in the Bahamas, Palau and Mexico. Smithsonian Contributions to Zoology 470: 1-47.

Kornicker, L.S. and T.M. Iliffe. 200o. Myodocopid Ostracoda from Exuma Sound, Bahamas, and from marine caves and blue holes in the Bahamas, Bermuda and Mexico. Smithsonian Contributions to Zoology 6o6: 1-98.

Neiber, M.T., F.C. Hansen, T.M. Iliffe, B.C. Gonzalez and S. Koenemann. 2012. Molecular taxonomy of Speleonectes fuchscockburni, a new pseudocryptic species of Remipedia (Crustacea) from an anchialine cave system on the Yucatan Peninsula, Quintana Roo, Mexico. Zootaxa 3190: 31-46.

Pérez-Aranda, L. 1983a. Palaemonidae: Creaseria morleyi. Fauna de los cenotes de Yucatán 1. Universidad de Yucatán, Mérida. 11 pp.

Pérez-Aranda, L. 1983b. Atyidae: Typhlatya pearsei. Fauna de los cenotes de ucatán 3. Universidad de Yucatán, Mérida. 11 pp.

Pérez-Aranda, L. 1984a. Atyidae: Typhlatya mitchelli. Fauna de los cenotes de Yucatán 5. Universidad de Yucatán, Mérida. 14 pp.

Pérez-Aranda, L. 1984b. Cirolanidae: Cirolana anops. Fauna de los cenotes de Yucatán 7. Universidad de Yucatán, Mérida. 13 pp. 
Pérez-Aranda, L. 1984c. Mysidae: Antromysis cenotensis. Fauna de los cenotes de Yucatán 9. Universidad de Yucatán, Mérida. 11 pp.

Pesce, G.L. and T.M. Iliffe. 2002. New records of cave-dwelling mysids from the Bahamas and Mexico with description of Palaumysis bahamensis n. sp. (Crustacea: Mysidacea). Journal of Natural History 36(3): 265-278 (doi: 10.1080/00222930010005033).

Reddell, J.R. 1981. A review of the cavernicole fauna of Mexico, Guatemala, and Belize. Texas Memorial Museum, The University of Texas at Austin, Bulletin 27: 1-327.

Semarnat, 2010. Norma Oficial Mexicana Nom-059-Semarnat-2010, Protección ambiental- Especies nativas de México de flora y fauna silvestres- Categorías de riesgo y especificaciones para su inclusión, exclusión o cambio- Lista de especies en riesgo. Diario Oficial, 30 de diciembre de 2010.

Solís-Marín, F.A. and A. Laguarda-Figueras. 2010. A new species of starfish (Echinodermata: Asteroidea) from an anchialine cave in the Mexican Caribbean. Revista Mexicana de Biodiversidad 81: 663-668 (http://www.scielo.org.mx/scielo.php?script=sci_artte $\mathrm{xt} \& \mathrm{pid}=\mathrm{S} 1870-34532010000300007)$.

Yager, J. 1987. Speleonectes tulumensis, n. sp. (Crustacea, Remipedia) from two anchialine cenotes of the Yucatan Peninsula, Mexico. Stygologia 3: 160-166.

Authors' contribution statement: All authors made the species identifications; FA, TMI and JLV prepared the text; TMI, DB and SB conducted the field sampling; FA and SB prepared the figures.

Received: August 2014

Accepted: November 2014

Editorial responsibility: Luis E. Arruda Bezerra 